\section{Patenting of microorganisms}

\author{
Philip M. Webber
}

Abstract | Patents on microorganisms are far from new. In the brewing and baking industries, yeast has traditionally played an important part and patents for new types of yeast were granted in Belgium in 1833 and in Finland in 1843. But how can you patent a microorganism?

All patentable inventions must satisfy essentially the same criteria - that is, the invention must be novel and not obvious, it must have some industrial use, and the description part of the patent application must enable a person skilled in the relevant area of technology to put the invention into practice ${ }^{1}$.

\section{Novelty of a microorganism}

In patent terms, 'novel' means not previously 'made available to the public'. So the first person to find and isolate a new bacterium from a soil sample, for example, might have made a potentially patentable invention. If the bacterium is claimed in the patent application in an 'isolated' form, that form will be novel over the previously known mixture of that bacterium with numerous other microorganisms in the soil. If the bacterium is shown to have some practical use and is sufficiently different from other bacteria which have previously been known for that use, then the use and inventive step hurdles are likely to be overcome.

\section{How to make the microorganism}

But what about the enablement hurdle?

How can you describe - in words - a microorganism in a manner such that a skilled microbiologist can reproduce it? If the microorganism in question is a mutant of a known bacterium, and the mutation process is reproducible, then the mutant can probably be adequately described in the patent application. But what if the microorganism has never been known before? The answer is to deposit a sample of the microorganism under the Budapest treaty with an International Depository Authority (IDA; see BOX). Under this treaty, if a sample of the microorganism is deposited with one IDA, the enablement requirement is deemed to be satisfied in all of the countries that have signed the Treaty.

\section{When to deposit \\ A number of countries and patent offices (notably the European Patent Office) require a sample of the microorganism to be depos- ited before the patent application is filed (and before the filing of the priority application if priority is to be valid ${ }^{2}$ ). So if the proposed fil- ing date of the patent application (or priority application) is approaching, steps should be taken to ensure that a sample of the micro- organism is deposited in good time. The depositor should, in particular, ensure that adequate time is allowed for delays in the mail or customs formalities (if the sample is being sent by mail), incorrectly filled-in forms, and the possibility that the sample is found to be non-viable by the IDA and that a replacement sample is therefore required.}

\section{INTERNATIONAL DEPOSITORY AUTHORITIES (IDAs)}

IDAs are internationally recognized organizations, each of which accepts and stores samples of a defined range of microorganisms - for example, bacteria, fungi, viruses, seeds, hybridomas and so on. Examples of IDAs include the American Type Culture Collection (ATCC), the European Collection of Cell Cultures (ECACC) and the Deutsche Sammlung von Mikroorganismen und Zellkulturen (DSMZ).

If the microorganism is to form the subject of a patent application, the microorganism should be deposited under the terms of the Budapest Treaty on the International Recognition of the Deposit of Micro-organisms for the Purposes of Patent Procedure. If the requirements of this treaty are satisfied, the microorganism will be deemed to satisfy the enablement requirements of countries that are members of the treaty (note that not all countries have signed the treaty). Once the sample has been deposited, the IDA is obliged to check the viability of the deposited organism and then to issue a Deposit Receipt and Viability Statement, copies of which are often required by the patent offices in order to satisfy themselves that the organism has been deposited.

Currently there are 36 IDAs, and 60 countries (including the European Patent Office) have signed the Budapest Treaty.

\section{Submitting details of the deposit}

Most patent offices require details of the IDA, the deposit number and deposit date to be included in the patent application on filing or to be added to the patent application within a set time (often within 16 months of the earliest priority date). A short description of the characteristics of the microorganism might also have to be included in the patent application. Practice on these points varies from country to country and it is therefore prudent to include all of this information in the patent application on filing, if possible.

\section{Issuing of samples of the deposit}

The availability to the public of samples of the deposited microorganism is dictated by the national laws that apply to the patent offices in question. Under certain circumstances in some countries (for example, before the grant of a European patent), the depositor can request that samples of the microorganism are only given to an expert nominated by the requestor.

\section{Patentable subject matter}

In the US, one of the most famous patents on microorganisms is that granted to Chakrabarty $^{3}$. The claims of this patent include "A bacterium from the genus Pseudomonas containing therein at least two stable energy-generating plasmids, each of said plasmids providing a separate hydrocarbon degradative pathway". The bacteria were useful for degrading oil-spills. In 1980, the US Supreme Court was called upon to decide whether or not such man-made bacteria were patentable in the US. The positive answer that the US Supreme Court gave to this question opened the flood-gates in the US for patent claims to transgenic organisms.

Frank B. Dehn \& Co., Patent and Trade Mark Attorneys, 179 Queen Victoria Street, London, EC4V 4EL, UK. e-mail:philipw@frankbdehn.com doi:10.1038/nrd1934

Webber, P. M. Protecting your inventions: the patent system. Nature Rev. Drug Discov. 2, 823-830 (2003). Webber, P. M. Priority patent applications. Nature Reviews: Drug Discov. 4, 877 (2005).

3. Chakrabarty, A. M. Microorganisms having multiple compatible degradative energy-generating plasmids and preparation thereof. US patent 4,259,444 (1981). 